\title{
Phytohormone targeting in plant tissues
}

\author{
Miroslav Strnad*, Ondrej Novak, Jakub Rolcik, Danuse Tarkowska, Jiri Gruz, Karel Dolezal \\ From IUFRO Tree Biotechnology Conference 2011: From Genomes to Integration and Delivery \\ Arraial d Ajuda, Bahia, Brazil. 26 June - 2 July 2011
}

\section{Background}

The identification and quantification of plant hormones in plant tissues are necessary for physiological studies of their metabolism and mode of action. The major problem associated with plant hormone analysis is that the amount of phytohormones present endogenously in plant tissues is very low, usually in the range of fmol to $\mathrm{pmol} / \mathrm{g}$ fresh weight.

\section{Methods}

Homogenization and extraction with organic solvents was done in one microcentrifuge tube and accelerated by crushing the plant material in a vibration mill. The extracts from minute amounts of fresh plant material were immediately purified using a solid-phase extraction (C18, C8, Oasis ${ }^{\mathrm{TM}}$ HLB cartridges)in combination with ion-exchange and/or immunoaffinity purification. A fast chromatography technique, the ultra performance liquid chromatography (Acquity ${ }^{\mathrm{TM}}$ UPLC,Waters) was coupled to triple quadrupole mass spectrometer (Xevo ${ }^{\mathrm{TM}} \mathrm{TQ}$ MS, Waters) equipped with an electrospray interface (ESI) and the unique performance of collision cell ScanWave ${ }^{\mathrm{TM}}$. The mass spectrometric conditions were optimized for each analyte and quantification was obtained by multiple reaction monitoring (MRM) of precursors and the appropriate product ions.

\section{Results and discussion}

We found that a combination of different sorbents, reverse phases and ion-exchange phases, was the best tool in the one-step purification, giving a total extraction recovery ranging between $50-80 \%$ for all studied biologically active compounds. In MRM mode, the detection limit for most of phytohormones (cytokinins [1,2], auxins [3], abscisic acid [4], gibberellins, brassinosteroids) as

\footnotetext{
* Correspondence: miroslav.strnad@upol.cz
Laboratory of Growth Regulators, Faculty of Science, Palacky University \&

* Correspondence: miroslav.strnad@upol.cz Institute of Experimental Botany AS CR, Slechtitelu 11, Olomouc, CZ-783 71, Czech Republic
}

(c) 2011 Strnad et al; licensee BioMed Central Ltd. This is an open access article distributed under the terms of the Creative Commons Attribution License (http://creativecommons.org/licenses/by/2.0), which permits unrestricted use, distribution, and reproduction in any medium, provided the original work is properly cited. well as phenolic acids [5] and mammalian steroids [6] was close to $1 \mathrm{fmol}$ and achieved linear range was at least five orders of magnitude. Use of our procedures can allow the quantification of plant hormones and their derivatives (in total 145 compounds) in very limited amounts of material, ca. $100 \mathrm{mg}$ FW. The methods provide substantial improvements in terms of robustness, sensitivity, selectivity, convenience, through-put and cost-effectiveness over previous methods published.

\section{Conclusions}

The application of new analytical approaches based on UPLC separation makes possible a new direction in plant hormone research. We believe that UPLC-ESI(+) MS/MS technology can be used for fast and sensitive quantitative analysis showing reproducibility in the plant hormones profiling in different tree extracts.

\section{Published: 13 September 2011}

\section{References}

1. Novak O, Hauserova E, Amakorova P, Dolezal K, Strnad M: Cytokinin profiling in plant tissues using ultra-performance liquid chromatography-electrospray tandem mass spectrometry. Phytochem 2008, 69(11):2214-2224.

2. Tarkowski P, Vaclavikova K, Novak O, Pertry I, Hanus J, Whenham R, Vereecke D, Sebela M, Strnad M: Analysis of 2-methylthio-derivatives of isoprenoid cytokinins by liquid chromatography-tandem mass spectrometry. Anal. Chim. Acta 2010, 680(1-2):86-91.

3. Pencik A, Rolcik J, Novak O, Magnus V, Bartak P, Buchtik R, Salopek-Sondi B, Strnad M: Isolation of novel indole-3-acetic acid conjugates by immunoaffinity extraction. Talanta 2009, 80(2):651-655.

4. Tureckova V, Novak O, Strnad M: Profiling ABA metabolites in Nicotiana tabacum L. leaves by ultra-performance liquid chromatogramyelectrospray tandem mass spektrometry. Talanta 2009, 80(1):390-399.

5. Gruz J, Novak O, Strnad M: Rapid analysis of phenolic acids in beverages by UPLC-MS/MS. Food Chem 2008, 111(3):789-794.

6. Simersky R, Novak O, Morris DA, Pouzar V, Strnad M: Identification and quantification of several mammalian steroid hormones in plants by UPLC-MS/MS. J. Plant Growth Regul 2009, 28(2):125-136.

doi:10.1186/1753-6561-5-S7-P75

Cite this article as: Strnad et al:: Phytohormone targeting in plant tissues. BMC Proceedings 2011 5(Suppl 7):P75. 